Library

Center for Research on

Economic Develooment

506 Eost Liberty Street

Ann Arbor, Mishigan 48708

\title{
Credit Controls as Instruments \\ Of Development Policy \\ In the Light of Economic Theory
}

\author{
by
}

OMOtunde E. G. JoHNSON

CRED Reprints

No. 40

Center for Research on Economic Development

University of Michigan

Ann Arbor, Michigan 48108 


\section{Center for Research on Economic Development CRED Reprints}

No. 27. "The Rediscovery of Exports by the Third World" by Richard C. Porter and Charles P. Staelin. (Foreign Trade Review, January-March 1972, pp. 523-539)

"No. 28. "Budget Policy and Economic Stability in Postwar Japan" by Wayne Snyder and Tsutomu Tanaka. (International Economic Review, Vol. 13, No. 1, February 1972, pp. 85-110)

*No. 29. "The Cost of Tying Aid: A Method and Some Colombian Estimates" by Thomas L. Hutcheson and Richard C. Porter. (Princeton Studies in International Finance, No. 30, March 1972, 53 pp.)

No. 30. "The Development Process" by 0 . Aboyade, and "Comments on Professor Aboyade's Paper" by Wolfgang F. Stolper. (Reconstruction and Development in Nigeria edited by A. A. Ayida and H. M. A. Onitiri. Published by the Nigerian Institute of Social and Economic Research, 1971, pp. 34-80)

No. 31. "Comments on Gustav Ranis' 'Relative Prices in Planning for Economic Development" by Peter Eckstein and Wolfgang F. Stolper. (International Comparisons of Prices and Output edited by D. J. Daly. Published by National Bureau of Economic Research, 1972, pp. 306-325)

No. 32. "The Effects of Tax Exemption on Investment by Industrial Firms in Colombia" by Richard E. Billsborrow and Richard C. Porter (Weltwirtschaftliches Archiv, Vol. 108, No. 3, 1972, pp. 396-426)

*No. 33. "Comment on the Role of Monetary Institutions" by Wolfgang F. Stolper. (Africa and Monetary Institutions edited by Rodrigue Tremblay. Published by Holt, Rinehart et Winston, Montreal, 1973, pp. 101-108)

*No. 34. "Internal Effects of Devaluation" by Wolfgang F. Stolper. (Africa and Monetary Institutions edited by Rodrigue Tremblay. Published by Holt, Rinehart et Winston, Montreal, 1973, pp. 411419) 


\section{OMOTUNDE E. G. JOHNSON*}

\section{Credit Controls as Instruments of Development Policy in the Light of Economic Theory}

IN THEIR QUEST for rapid economic development, developing countries have found it essential to divert resources to areas that are considered most productive in some social sense. As institutions engage in the transfer of command over resources from surplus to deficit units, commercial banks can influence the pace and pattern of development by the efficiency with which they mobilize and allocate savings and by the direction of their allocation of these savings. The importance of this bank activity is increased by the dearth of other types of private, financial institutions in these countries. In view of this, central bankers and others have noted with grave concern the fact that, to a large extent, commercial banks have allocated a supposedly disproportionate share of their funds to certain "traditional" activities. In particular, the banks have concentrated heavily on short-term, self-liquidating loans to finance foreign and domestic commerce. Medium- and long-term loans, especially for the finance of industry and agriculture, have largely been neglected. Moreover, the facilities of these banks tend to be available mainly-sometimes only-to established concerns in the urban areas $[1$, p. 367]. This generally means that concerns owned and managed by indigenous groups or individuals have been neglected. According to this view, the imbalance in the allocation of commercial bank funds has produced, and threatens to perpetuate, an imbalance in the pattern of development of these countries. In order to stem the flow of bank funds into "low-priority" areas and divert them to "high-priority"

\footnotetext{
*The comments of an anonymous referee on an earlier draft, which induced some tightening of the argument, is gratefully acknowledged. Sole responsibility for remaining errors and deficiencies is, of course, mine.
}

OMotunde E. G. Johnson, lecturer in economics at Fourah Bay College, University of Sierra Leone when this paper was written, is visiting research associate, Center for Research on Economic Development, University of Michigan. 
areas, credit-control policies have been urged and/or instituted. In this paper, I shall examine credit controls as attempts to equate private and social profitability and as tax-cum-subsidy schemes, and conclude that there is no logical basis for them. Instead, other kinds of policies can be introduced that will not only achieve the desired goals sought by credit controls, but will do so more effectively and efficiently.

The paper does not aim at a critique of credit controls as short-term policies to control credit in times of inflation or other emergency conditions (e.g., wars, drought). Nor does it aim at examining particular techniques of credit controls. ${ }^{1}$ Instead, it is the basic rationale of credit controls, as instruments of development policy, to influence the long-term lending policies of banks in developing countries in order to achieve balanced economic growth that is here under examination. Although "banks" are emphasized in the paper, it will be clear that a substitution of "financial institutions" in general for "banks" (where credit controls extend to non-bank financial institutions) will not change the substance or significance of the paper.

\section{The Nature of Credit Controls}

Credit controls in developing countries have tended to be of three broad categories. ${ }^{2}$ First, there are the portfolio-ceiling devices. These generally involve the setting of ceilings on loans to be made for specified purposes or to certain specified sectors. The ceilings may be specified either in the form of percentages of loans and advances to be extended to different sectors or they may be stated in terms of the maximum aggregate amount of loans allocable to the specified sectors. Another type of portfolio-ceiling device is the setting of incremental ceilings specifying the maximum increases allowed for loans for various purposes.

Alternatively, the above devices may be put in the form of a requirement for prior approval to be obtained from the Central Bank for loans to be extended above specified levels or specified percentages to the different sectors. Or, the requirements for prior approval may be for loans, to specified sectors, to be augmented by stated amounts or percentages, within certain prescribed periods of time.

Secondly, there are the policies tied to the discount mechanism. The Central Bank may charge preferential rates in rediscounting paper originating in the sectors earmarked "high-priority" in order to provide an added

\footnotetext{
${ }^{1}$ Interested readers may consult Patel [11], especially pp. 80-84, for a discussion of credit control as a short-term expedient, and Brimmer [3], especially pp. 786-89, and Patel [11] for a discussion of the advantages and disadvantages of some of the more popular types of credit-control devices.

${ }^{2}$ See Andrew F. Brimmer [3] for more details of these policies and some of the countries that have introduced them.

${ }^{3}$ For example, Márquez [10, pp. 183-84] writes:
} 
incentive for the commercial banks to increase lending to these favored activities, or at least to reduce the private cost of funds to the favored activities. Or, the Central Bank may engage in discretionary alterations of the list of eligible types of paper in order to take account of alterations in the intensity with which it wants to push credit into different areas from time to time. Differential discount rates and alterations in the list of eligible paper are used where commercial paper is widely utilized as an instrument of private finance and where commercial bank rediscounting of such paper at the Central Bank usually occurs. These limitations hinder the use, or potential effectiveness, of these devices as instruments of credit controls in many developing countries, especially African countries, where the prerequisites are not fulfilled.

The third set of credit-control policies are those tied to reserve requirements. These most often involve linking differential reserve requirements to the composition of commercial bank portfolios. Banks whose portfolios conform to the requirements of certain prescribed percentages of loans to the "high-priority" areas are allowed to maintain lower cash or liquidity ratios than the normal ratio, which of course will continue to apply to banks which do not meet the credit requirements. The prescribed percentages and /or the associated cash or liquidity ratio may be changed as the Central Bank's emphasis shifts from one "high-priority" area to another. Alternatively, very high reserve ratios are imposed and banks are then given the option of keeping these reserves idle or investing them in certain specified assets $[10$, p. 184$]$.

\section{Credit Controls and the Equation of Private and Social Benefits}

The implicit theoretical basis for such credit controls has been that the private profitability (to the commercial banks) and the social profitability differ with respect to loans granted to the different sectors. ${ }^{3}$ In order not to confuse issues, it will be assumed here that this thesis is correct. That is, the case most favorable to credit controls will be considered. The question then becomes why the private profitability of loans to particular areas of the economy, in particular the "high-priority" areas, should differ from the true social profitability. One can conceive of at least three reasons why this could be so.

In the first place, the "true" creditworthiness of the particular users of funds in the "high-priority" sectors may be underestimated by commercial banks. This implies that it will be profitable for the commercial banks,

\footnotetext{
"If development of any social value is to be speeded up, considerable investment must go into fields producing goods and services for the large sectors of the population which, in Latin America, have very low incomes. However, private financial institutions will voluntarily undertake investment of this sort only to a limited extent because the short-run profitability of such investment is necessarily small."
} 
using their own discount rates, to expend some resources in estimating the "true" creditworthiness involved and in extending more loans and advances than they now do to these "high-priority" areas on the basis of the newly acquired information. It can then be argued that banks do not attempt to increase their knowledge about creditworthiness in these areas because of inertia and conservatism. But suppose it is argued, or can be shown, that the rate of return on commercial banks' search and other information-augmenting activities in these areas is very low as compared to their "traditional" uses of resources. It may still be possible to show that commercial banks do not in fact have comparative advantage in assessing the creditworthiness of certain institutions and individuals, and that these institutions and individuals are among the "high-priority" areas. Therefore, even though some of their funds will be more profitable to them if used in these areas instead of in their traditional areas, commercial banks are inhibited by ignorance of this fact and by the relatively high cost of finding out the truth. Socially profitable lines of credit are therefore not extended.

It can be similarly argued that these banks overestimate the "true" risk costs associated with extending, servicing, and collecting loans made to the "high-priority" sectors, or that the banks simply have relatively "high" costs of extending, servicing, and collecting such loans. Again, a major source of possible divergence between private and social profitability of extending loans to the "high-priority" areas is found.

There is a second possible reason for a possible divergence between private and social profitability of extending loans to the "high-priority" areas. This is a possible disparity between the commercial banks' desired rate of return on loans and the correct marginal social rate of time preference. Commercial banks, in short, might have "too high" a desired rate of return relative to the marginal social rate of time preference. The arguments for such a divergence, in general, are, of course, well known (see for example, Marglin [9] and Pigou [12]). Given such a divergence, one can argue that if all loans are discounted by the marginal social rate of time preference, some of the "high-priority" sectors will be found to warrant far more loans than they at present receive from the banks. This argument, unfortunately, can frequently be dismissed as irrelevant. For the high rate of discount used by the commercial banks, as compared to the true marginal social rate of time preference, can be made a case for more loans in general but not necessarily a case for altering the shares of loans going to different sectors. That is, even if banks grant loans on the basis of the correct marginal social rate of time preference, there is no reason to expect that they will not simply grant more loans to the same "traditional" areas to which they have granted such loans in the past.

Still another reason can be adduced to explain a possible divergence between social and private profitability or extending a greater fraction 
of bank loans to the "high-priority" areas. The long-range and wider impact of the development of these sectors on the economy as a whole may not be sufficiently incorporated into the private calculus of the banks, since neither the banks nor the particular firms and individuals of the "high-priority" sectors are able to capture the positive externalities of the latter's activities at sufficiently "low" cost. ${ }^{4}$ It is important to realize that the "high-priority" firms and individuals themselves must not be able to capture the external benefits. If they were able, their demand price for funds would incorporate these benefits and, indirectly, the commercial banks would also be induced to incorporate these benefits into their calculus. Given that the external benefits being discussed are captured neither by the banks nor by the "high-priority" areas, allocating a higher fraction of society's resources, than at present, to the "high-priority" areas will result in a higher net present value of the society's resources, whatever the discount rate used, provided that we look sufficiently far and wide in calculating the benefits.

Fundamentally, then, the case for credit controls as desirable in developing countries in order to direct the nation's resources into the most socially profitable uses boils down to this. Commercial banks (or financial institutions in general), in the first place, either underestimate the creditworthiness, and overestimate the risk, administration, and collection costs associated with extending loans to certain sectors, or have costs of assessing creditworthiness and risk, and of administering and collecting loans, in these sectors higher than the true social cost. In the second place, the commercial banks do not take into consideration the external benefits which expansion in the "high-priority" sectors will yield for the rest of the economy.

\section{The Distribution Effects of Credit Controls}

By reallocating credit, to alter the market-determined allocation of real resources, credit controls become implicit tax-cum-subsidy schemes. There are two methods by which they achieve this. One is by inflation and the other is by altering the profits of banks and their traditional clients vis-à-vis the "high-priority" sectors.

Consider the case of inflation. Policies tied to the discount mechanism, in particular, work through inflation. Take, for example, differential discount rates. Preferential Central Bank discount rates for paper orginating from the "high-priority" areas, or preferential treatment for such paper in rediscounting, enables private financial institutions to give added credit to the "high-priority" areas without serious threat to the credit available

\footnotetext{
${ }^{4}$ This seems to be the general implicit or explicit view of the true source of the divergence. See, for example, the passage cited from Márquez [10] in n. 3.
} 
for their traditional clients. The policy induces banks to increase their demand for paper issued by the "high-priority" sectors, at any given interest rate, as well as to give such instruments increased favorable treatment in any credit rationing. The result, ceteris paribus, is increased purchases of these instruments by commercial banks. Insofar as banks do not start with actual reserves greater than their desired reserves, they will be expected to rediscount, at the Central Bank, the instruments they would not normally purchase but for the preferential treatment. The funds are then again available for their traditional clients. Thus, commercial banks become simply media through which the Central Bank purchases paper originating from the "high-priority" areas. The net effect is expansion of the money supply. When the banks start with greater than desired reserves, with which they purchase the "high-priority" paper, the money supply increase occurs even if they do not rediscount at the Central Bank.

The increased money supply provides the means whereby the preferred sectors bid away resources from other firms. The consequence is rising prices of resources. As the owners of resources employed in the preferred sectors, who now have increased income, attempt to bid away consumer goods and services from the rest of the population, the price of consumer goods and services increases. The extent and duration of the price increases will depend upon the elasticities of supply of resources and of consumer goods and services, the rate and duration of the monetary increase, the propensity to save, and the elasticity of demand for money with respect to price changes-in well-known ways.

In short, the differential discount rates engender inflation, which is the mechanism by which the other sectors of the economy are taxed to subsidize the preferred sectors. The incidence of the inflation tax will depend, as is well known, especially on the distribution of financial claims, the structure of contractual relations, and on bargaining strength. A consequence is that, apart from the well-known real cost of inflation, the secondary distributive effects (due to differential incidence of the inflation among the taxed) may not be desirable in the eyes of the authorities, whether for political or for social reasons.

When credit-control policies do not tax and subsidize through inflation, they do so through implicitly taxing the banks and their traditional clients to subsidize the "high-priority" sectors. This form of the tax-cum-subsidy is especially associated with portfolio-ceiling devices and policies tied to reserve requirements. The aim of these policies is to augment the ratio of loans going to the "high-priority" areas ("high-priority" loans) to total earning assets, of banks. Assume banks were in equilibrium before the credit controls. There are two attributes of marginal increments of such "high-priority" loans which made them less attractive to banks than the units of other earning assets which they would have replaced. They are less liquid and are less profitable given liquidity. Thus, to force banks 
to increase the ratio of "high-priority" loans to total earning assets is to reduce the liquidity and profitability of their earning assets. The effect of reduced liquidity is to cause banks to want to alter the composition of their "non-high-priority" earning assets in such a way as to achieve increased liquidity. This would generally mean substitution of government securities and large business loans for consumer debt and small business loans. But the effect of the reduction in profitability is to cause banks to want to alter the composition of these same assets so as to substitute more profitable assets (in a schedule sense), such as business and consumer loans, for less profitable assets, such as government securities. The ultimate result would depend greatly on how the credit-control policy affects the liquidity of "high-priority" loans and on how much less profitable are the "high-priority" loans. But two things are clear. First, of the firms not among the "high-priority" sectors, the big, well-established firms gain more bank credit at the expense of small firms, consumer credit, and government securities. This readjustment of banks' portfolios among "nonhigh-priority" sectors' instruments may not be salutary to the authorities. Secondly, as long as the "high-priority" loans are not as liquid, ceteris paribus, as the earning assets they replace, the banks will not be willing to substitute among their earning assets enough to neutralize the adverse effects on their profitability. In the new equilibrium after the credit control, banks' earning assets will, therefore, be less profitable than before. This reduced profitability of their earning assets is the implicit tax on banks. The real cost of the tax on the banks is, of course, the reduction in their utility due to the reduced money income and reduced liquidity now yielded by their earning assets.

Since the implicit tax on banks restricts their ability to compete for loanable funds vis-à-vis the open market (including here the unorganized money markets [15]), loanable funds from ultimate suppliers are diverted towards the open market and away from banks. This constitutes a further "tax" on the banks (and any other financial institutions to which credit controls apply).

The reduced bank funds going to the banks' traditional clients cause them to turn to other sources of funds. These may be open-market domestic sources, foreign sources, or internal sources. If they turn to open-market sources, the traditional clients bid up the prices of these funds in the attempt to attract them away from other users. The rise in interest rates which ensues will continue until the increased amount demanded in the open market by the banks' traditional clients equals the amount released by other borrowers plus the increased amount supplied by market lenders of funds. The effect of the rise in interest rate is to impose an implicit tax on the banks' traditional clients as well as to redistribute wealth-away from net borrowers towards net lenders, ceteris paribus.

But such open market domestic sources accessible to the banks' traditional 
clients are practically nonexistent in many developing countries. These firms are therefore more likely to turn to foreign sources and/or internal sources. If foreign sources, then there is both added interest cost and a foreign exchange cost to be incurred by the banks' traditional clients. Again, there is an implicit tax on them. ${ }^{5}$

Thus, an effect of the policy of compelling banks to increase the proportion of loans to the "high-priority" areas in their total earning assets portfolio is a two-fold redistribution of wealth. First, the policy redistributes wealth away from banks and their traditional clients towards the "high-priority" borrowers. This is accomplished by forcing banks to lend to the "highpriority" areas such that their wealth is reduced, by forcing the banks' traditional clients to turn to higher cost sources of funds, and by enabling the "high-priority" sectors to borrow from banks at lower cost than under competitive conditions. Secondly, ceteris paribus, the policy redistributes wealth away from net borrowers to net lenders of open-market funds.

If the banks' traditional clients turn to internal sources of funds, the result is the same as above, as long as these were not undesired idle balances. These balances would then have to be withdrawn from their previous uses, creating shortages in these latter areas and the consequent search for alternative sources of funds. If the traditional clients have undesired idle balances, then the velocity of monetary circulation increases and the tax-cum-subsidy is effected through inflation.

\section{The Welfare Costs of Credit Controls}

Apart from the well-known welfare costs of inflationary credit controls, there are other kinds of welfare costs associated with credit-control policies in general. Like other financial institutions, banks supply indirect securities to ultimate lenders in exchange for funds used for the purchase of primary securities [4]. The more efficient they are at intermediation, the greater will be the ratio of indirect securities to primary securities held by ultimate lenders of funds. The comparative advantage of financial institutions in mobilizing savings and allocating them to competing investors leads to increased interest payments to savers, lower interest rates to investors, and reduced transaction costs in getting funds from surplus to deficit units.

\footnotetext{
${ }^{5}$ Here it is not clear that anyone within the economy directly gains (i.e., is implicitly subsidized) by the traditional clients' borrowing abroad. It might be thought that there is some gain to the economy in the sense that additional foreign exchange becomes available. But it is not difficult to see that this is an inefficient way of augmenting foreign exchange. First, there are the welfare and other costs connected with credit controls. Secondly, the social cost of the additional funds made possible by the increased foreign exchange is greater than the social value (marginal contribution to real income) of these funds. Lastly, increased amounts of resources now go into foreign exchange transactions. These resources must be diverted from other more socially productive uses except where they were previously idle.
} 
Thus, saving and investment, as well as the social rate of return on society's investment resources, are augmented.

The effect of the implicit tax on financial institutions is to lower the rate of return on the intermediary function, reduce the supply of indirect securities (in a schedule sense) and, given demand, lower the ratio of indirect to primary securities in the portfolios of final lenders. The result is a lower rate of interest on savings, higher interest costs of investment, and greater transactions costs to society for transmitting funds from surplus to deficit units. Lower savings and investments, more direct financing, and lower return on investment are the ultimate consequences. But the reduced supply of indirect securities is not due to any increase in their social opportunity costs and is thus socially inefficient. The ultimate fall in the flow of consumer goods and services produced by the society's resources, as compared with the social optimum, leads to a reduction in consumer welfare. ${ }^{6}$

The above welfare cost is indeed significant for many developing countries. In many of these countries there are very few types of financial intermediaries and very few primary securities accessible at reasonable cost to households. Moreover, capital markets are invariably highly inefficient and primitive. Indeed, many of these countries have nothing in the way of a Stock Exchange. The implication is that the real cost (reduced flow of consumption goods over time) of credit controls of the form under discussion can be especially significant.

The credit-control policies, as we have seen, often mean differential interest rates. In particular, the interest cost increases for the "non-highpriority" sectors and decreases for the "high-priority" sectors. The effect is to cause the marginal rate of substitution of capital for noncapital factors of production to alter. In equilibrium, this marginal rate will be higher for the "non-high-priority" sectors than for the "high-priority" sectors. This has two implications for welfare. In the first place, society will not be operating on its efficiency locus and outermost production-possibility locus (given tastes, resources, and technology). Thus, in the final consumer equilibrium, welfare is at a lower level than if the marginal rates of technical substitution were equalized. In the second place, the differential marginal rates of technical substitution make black marketing profitable. The "highpriority" sectors will sell some funds borrowed at preferential rates to the other sectors. But the transaction costs involved in this trading use up valuable resources that could be more profitably employed elsewhere.

Apart from the above welfare costs, at least one other can be deduced. Among the banks' traditional clients, the incidence of the tax is not neutral.

\footnotetext{
${ }^{6}$ If banks are but one of many financial institutions in a country and only banks are implicitly taxed by credit controls, apart from the decreased supply of indirect securities, there is also a redistribution of shares among suppliers away from banks and towards the other institutions. The importance of banks in intermediation diminishes [6].
} 
By "neutral" incidence we mean incidence which leaves relative costs, and hence supply prices, unchanged. The incidence depends crucially on two factors: the percentage of funds borrowed from banks and access to funds from nonbank sources. The greater the percentage of its funds previously borrowed from banks, and the more restricted its access to nonbank sources, the greater the incidence of the tax imposed by credit controls on any given bank's traditional client. Thus, not all of those discriminated against by the credit-control policy are equally taxed by the policy. The importance of this is that changes in relative costs and supply prices occur. In particular, those "non-high-priority" traditional clients that borrowed a large fraction of their funds from banks and have very limited access to alternative sources, experience increased cost of production relative to those that previously borrowed only a small fraction of their funds from banks and have very good alternative sources of funds. The credit-control policy, therefore, results in alterations in relative supply prices of commodities among these sectors that do not reflect changes in relative, social opportunity costs of production. Relative commodity prices are therefore "false" in that they do not represent relative social opportunity costs of production, resulting in a lower-than-potential level of welfare for consumers.

\section{Other Problems with Credit Controls}

Besides the welfare costs there are other important considerations which make one believe that credit controls are inferior to other feasible alternative credit-reallocation schemes.

It seems desirable that credit-reallocation schemes should not impose added restriction on the monetary authorities' ability to control the money supply. There are already important factors making it difficult for the monetary authorities in developing countries to effectively control the money supply (see, e.g. [1]). Credit controls, especially those involving discount rates, as we have seen, often involve increases in the money supply. This can cause the monetary authorities to lose some of whatever control they have over the money supply. ${ }^{7}$

It is, in our view, also desirable that credit-reallocation schemes do not occasion loss of control over either the global amount of subsidies or the amounts of such subsidies going to the different sectors. Tax-cumsubsidy schemes have real opportunity costs and benefits to society. In this case, there is, on the one hand, a loss of consumers' surplus in those sectors forced to grow slower than before or to decline absolutely. This is the real (gross) cost of the policy. On the other hand, there is an increase

\footnotetext{
${ }^{7}$ It is little wonder that belief in the relative unimportance of the money supply as a policy variable has sometimes formed a conceptual basis for imposing direct credit controls. For a recent discussion of this in the case of Britain, see Hodgman [5].
} 
in consumers' surplus in those sectors that are induced to grow faster than otherwise. This is the real (gross) benefit. It is, therefore, desirable that the absolute amount of the tax and the amount and direction of the subsidies to the different sectors be explicit, with funds being raised and allocated in such a way that the amounts involved and their directions can be altered according to real social opportunity costs and benefits. Credit controls are wanting in this respect. The "tax" imposed on the commercial banks and other firms and the amount of the subsidies going to the different "high-priority" sectors are all not easy to assess and/or quantify. They, therefore, do not facilitate rational strategies designed to achieve some desirable, socially optimal allocation of credit.

Uncertainty has adverse effects on intermediation. It seems desirable, therefore, that credit-reallocation schemes should not increase the uncertainty faced by banks and other financial institutions in their economic activities. But in their attempt to achieve "optimal" allocation (as they see it) by variation of the implicit tax and implicit subsidies, the Central Bank is likely to vary credit controls frequently and unpredictably in a way that might increase the uncertainty of commercial banks in their activities.

\section{The Alternatives}

We have seen that there are externalities connected with the "highpriority" sectors' demand for bank credit for two reasons. In the first case, the effective demand of these sectors for resources including bank credit is low because, in their productive activity, they are "unable" to capture profitably the full value created by their activities, and the noninternalized portion of this value is significant enough to warrant much more use of society's resources in these activities. In the second case, banks underestimate the true effective demand of these sectors for bank credit because banks are "poor" in estimating this effective demand.

Once the issue is put in this form, it is clear that credit controls are not the answer. Rather, it is explicit tax-cum-subsidy in the first case, and, in the second case, the creation of financial institutions with actual or potential comparative advantage in assessing the creditworthiness of these sectors and in administering and servicing loans to them. Consider the first case. It is the whole society that captures the positive externality flowing from the activities of the "high-priority" areas. For optimal internalization of these externalities, it seems desirable that the whole society should "pay" for these external benefits. Thus, what is called for is an explicit tax imposed on the rest of the community and the proceeds used to give an explicit output subsidy to the "high-priority" sectors in accordance with the estimated external benefits conferred. Similarly, in the second 
case, what is wanted are institutions with supposed comparative advantage in assessing creditworthiness and in administering and servicing loans to the sectors considered "high-priority" sectors, with a view to reducing the cost of attaining any given amount of information and effecting any given amount of servicing. By working through such institutions, we can also ensure that the "right" amount (as assessed by the equimarginal principle) of resources go into assessing creditworthiness and into administering and servicing loans. These "new" institutions can borrow funds from the commercial banks at market rates of interest and lend these funds out to the "high-priority" sectors and/or they can be given initial, "sizeable" working capital from state funds and then be left to work on their own. In this second case, there is, in fact, no need for subsidization of the "high-priority" sectors. Indeed, the activities of the new financial institutions are, socially and privately, profitable. ${ }^{8}$ Note that in both of these alternatives, the Central Bank is not at all involved. ${ }^{9}$ In addition, all the welfare costs and other disadvantages of credit controls discussed above are avoided.

\footnotetext{
${ }^{8}$ That the government can set up financial institutions for the purpose of financing certain "high-priority"' sectors neglected by private institutions has, of course, been realized before and, indeed, many countries have set up such institutions. What has not been clearly understood is that such institutions make credit controls superfluous and indeed, in a welfare sense, "harmful." Patel, for example, argues that if "the credit needs of the community are not met adequately by existing institutions the government can set up new or specialized credit institutions" [11, p. 77]. But he proceeds to argue that "if private banks are to be assigned a significant role in the economy, it becomes necessary to influence their decisions" (p. 77). Moreover, he continues to state that if "it is not possible to induce banks to make productive loans on an adequate scale, some measure of compulsion may be used" (p. 78).
}

One writer who has impressed us as seeing that credit controls are unnecessary is $J$. Márquez. He argues that "if the authorities wish to favor certain activities or groups with access to funds which these activities or groups cannot ordinarily obtain from private financial institutions, the most expedient and clear-cut solution is the creation of official financial institutions which will undertake this financing" $[10, p .186]$. The argument in this paper is that, from a welfare economics standpoint, this is the "correct" solution to the problem.

${ }^{9}$ It can, of course, be argued that the Central Bank can or should enter into the commercial banking business. Indeed, no less an authority than R. S. Sayers [13] has argued that in developing countries the Central Bank should be not merely a banker to the government and the commercial banks, but should also be a banker to the public. The Central Bank would, he argued, have a comparative advantage over the usual foreign banks in spreading banking services and facilities to the hinterland and more populous parts of the country (p. 117). Also, even though the Central Bank can aid in the development of private indigenous commercial banks, the development of "sound commercial banking may not be fast enough to make adequate provision for the country's economic potentialities, and the Central Bank should be ready to step in to fill the gaps"'(p. 118). Moreover, conducting ordinary banking business in the remoter parts of the country would help to give the Central Bank direct knowledge of general economic conditions (p. 118).

But the first two advantages would be realized by state financial institutions not connected with the Central Bank, and the last advantage could be obtained by simply endowing the Central Bank with a research branch like most of them already have. When these points are placed on top of the disadvantages of central banks acting as ordinary commercial banks discussed by Sayers himself (p. 116), the presumption is against central banks involving themselves in this area.

The Central Bank can help in the setting up of the state financial institutions. But its help must be confined to the technical details of getting started. 


\section{Political-Economic Considerations}

In many developing countries, banks and their traditional clients all tend to be predominantly foreign owned. Thus, one often hears nationals complaining of arbitrary discrimination by banks against indigenous enterprise. Let us assume that this is the case in order not to detract from our main argument. The question is whether credit controls are the "correct" set of policies. Again, whatever the nature of the distortion that the banks' policy has caused and the authorities wish to tackle, instituting credit controls is not the correct approach. For what the banks' policy of arbitrary discrimination has meant is that commercial banks have effectively subsidized foreign firms by making low-return loans to the latter when higher-return loans to indigenous enterprise, or investment in other assets, would have been more profitable to the banks themselves. What one needs to know is why banks have found it in their interest (i.e., "profitable') to do this. Then the problem can be tackled head on. For instance, suppose foreign enterprises are able to act as a single, unified group in bidding for bank funds. Then they might be able to impose "unfavorable" terms on banks such as the limiting of their lending to indigenous entrepreneurs. But then the sources of the oligopsonistic power of the foreign firms need to be tackled directly. Credit controls are not necessary and are inefficient.

It is our view that in such situations credit controls are often merely devices to impose implicit taxes on foreigners to subsidize indigenous enterprise. A little investigation reveals the problem that is to be tackled here. The allocation of bank credit can be said to be inefficient because it neglects the public good "nationality." For optimal allocation of credit, the return to the capital good "nationality" must be considered. ${ }^{10}$ But if this is the case, then a policy which imposes an excise tax on the output of foreign firms and grants a subsidy per unit of output produced in indigenous firms is a more direct and efficient way of tackling the problem. ${ }^{11}$ At any rate, credit controls are an inefficient device for tackling the problem.

\section{Concluding Remarks}

In this paper, it has been argued that credit-control policies have ultimately been conceptually based on a proposed divergence between private and

\footnotetext{
${ }^{10}$ Albert Breton [2] was the first to develop this notion of "nationality" as a collective capital good, yielding monetary and nonmonetary returns, in which rational individuals might find it "profitable" to invest scarce resources.

${ }^{11}$ The pure economics of policies to minimize the real cost of nationalistic policies have been discussed by the present writer in [7].
} 
social profitability of extending loans to certain "high-priority" areas of the economy. On the assumption that such a divergence in fact exists, it has been argued that there are at least two alternative schemes which will capture all the supposed benefits of credit controls but without as much of the accompanying cost. Credit controls were also seen as attempts to protect indigenous enterprise from arbitrary discrimination by banks in allocating credit, and/or to internalize the return from the public good "nationality." But in these areas also, credit controls are indirect and inefficient ways of tackling the problem.

Certain issues have been deliberately avoided in order not to detract from the thrust of the paper. In particular, three significant issues have been avoided. First, there is the question of whether government interference is desirable in this area. It seems that developing countries are committed or determined to effect a "fair" amount of such involvement in this area, and the economist can spend his time more valuably worrying about the efficiency of alternative ways of such interference and involvement than about anything else. Secondly, the question of the relative efficiency of state versus private enterprise in the light of " $x$-efficiency" [8], property rights, and so forth, was avoided. No doubt this is important, but it was implicitly assumed throughout that the state enterprise is no less efficient than the private, again to avoid detracting from the thrust of the paper. A third important issue avoided is whether or not, empirically, there is really an unsatisfied effective demand (at socially optimal prices) in those areas into which commercial banks have traditionally not poured funds [14]. The assumption of the existence of external benefits of their activities, which the so-called "high-priority" (but neglected) areas are unable to capture, makes it obvious that their private effective demands for funds do not reflect the true social effective demands for these funds.

\section{Literature Cited}

1. Broomfield, A. I. "Monetary Policy in Underdeveloped Countries," in Morgan, Betz, and Choudry, Eds., Readings in Economic Development. Belmont, California, 1963.

2. Breton, Albert. "The Economics of Nationalism," Journal of Political Economy, 72 (August 1964), 376-86.

3. Brimmer, A. F. "Central Banking and Economic Development: The Record of Innovation," Journal of Money, Credit, and Banking, 3 (November 1971), 780-92.

4. GuRley, J. G. and E. S. Shaw. Money in a Theory of Finance. Washington, D.C.: The Brookings Institution, 1960.

5. Hodgman, D. R. "British Techniques of Monetary Policy: A Critical Review," Journal of Money, Credit, and Banking, 3 (November 1971), 760-79. 
6. "Selective Credit Controls," Journal of Money, Credit, and Banking, 4 (May 1972), 342-59.

7. Johnson, O. E. G. "On the Economics of Localization in Africa," Eastern Africa Economic Review, 4 (December 1972).

8. Leibenstein, H. "Allocative Efficiency vs 'X-Efficiency',' American Economic Review, 56 (June 1966), 392-415.

9. Marglin, S. A. "The Social Rate of Discount and the Optimal Rate of Investment," Quarterly Journal of Economics, 77 (February 1963), 95-111.

10. Márquez, J. "Financial Intermediaries and Economic Development," in $\mathbf{H}$. S. Ellis, ed., Economic Development for Latin America. London: Macmillan and Co. Ltd., 1963.

11. Patel, I. G. "Selective Credit Controls in Underdeveloped Economies," International Monetary Fund Staff Papers, 4 (1954-55), 73-84.

12. Pigou, A. C. The Economics of Welfare. 4th ed. New York: Macmillan, 1932.

13. SAYers, R. S. "Central Banking in Underdeveloped Countries," in R. S. Sayers, Central Banking After Bagehot. Oxford: Clarendon Press, 1958.

14. Schatz, S. P. "The Capital Shortage Illusion: Government Lending in Nigeria," Oxford Economic Papers, 17 (July 1956), 309-16.

15. WAI, U TUN. "Interest Rates Outside the Organized Money Markets of Underdeveloped Countries," International Monetary Fund Staff Papers, 6 (November 1957), 80-142. 



\section{CRED Reprint Series}

*No. 35. "An Evaluation of Short-Term Forecasts of Coffee and Cocoa" by J. Kimball Dietrich and Alfredo D. Gutierrez. (American Journal of Agricultural Economics, Vol. 55, No. 1, February 1973, pp. 93-99)

No. 36. "The Birth of a Bill Market" by Richard C. Porter (Journal of Development Studies, April 1973, pp. 439-450)

No. 37. "Pragmatism and the Primary School: The Case of a NonRural Village" by Joyce L. Moock. (Africa, 1973, pp. 302-316)

No. 38. "The Impact of the Commonwealth Preference System on the Exports of Latin America to the United Kingdom" by John Naranjo and Richard C. Porter (Journal of Development Studies, Vol. IX, No. 4, July 1973, pp. 581-597)

No. 39. "Authoritarian Politics in Unincorporated Society: The Case of Nasser's Egypt" by Clement Henry Moore (Comparative Politics, January 1974, pp. 193-218)

No. 40. "Credit Controls as Instruments of Development Policy in the Light of Economic Theory" by Omotunde E. G. Johnson (Journal of Money, Credit, and Banking, February 1974, pp. 85-99)

* not available 
